\title{
METODE PEMBANGKITAN IDE KREATIF DALAM PENCIPTAAN SENI
}

\author{
Edi Eskak *)
}

\begin{abstract}
ABSTRAK
Ide merupakan konsep pemikiran yang akan diwujudkan menjadi karya, tanpa ide seniman tidak akan bisa menciptakan karya seni. Ide menjadi penting karena merupakan titik tolak menciptakan suatu karya seni, namun dalam mengeksplorasi ide, banyak seniman terkendala dalam menemukan ide yang akan dituangkan menjadi karya. Maka perlu dikaji berbagai metode pembangkitan ide kreatif dari berbagai sumber yang dapat diaplikasikan guna membangkitkan ide-ide baru dalam penciptaan seni. Metode yang dikaji adalah: membaca, observasi, curah gagasan, berpikir lateral, serta bersosialisasi dan berdiskusi, Membaca meningkatkan pengetahuan dan memperluas wawasan. Observasi merupakan upaya mendapatkan pengetahuan baru yang mendalam dengan pengamatan, sehingga seniman mendapatkan ide-ide baru. Bila mengalami ketiadaan ide, seniman dapat melakukan curah gagasan yang dilakukan secara bebas sehingga dapat terhindar dari kebuntuan ide. Berpikir lateral merupakan cara penyegaran pikiran dengan mencoba keluar dari kotak kemapanan, rutinitas, atau dari penjara idiologi, agar menemukan ide inovatif dalam penciptaan seni. Bersosialisasi dan berdiskusi memperbanyak teman untuk bertukar pikiran serta mendapatkan pengalaman yang inspiratif.

Kata kunci: ide, kreativitas, dan penciptaan seni,
\end{abstract}

\begin{abstract}
The idea is the concept of thinking translated into the work. An artist will not be able to create art work with no idea. The idea is a starting point to create an art work so that become as an important issue. However in exploring the idea, many artists are constrained in finding it so that will be poured into the work. Then it is necessary to study various methods of generating creative ideas from a variety of sources that can be applied in order to generate new ideas in the creation of art. The methods studied were: reading, observation, brainstorming, lateral thinking, as well as socializing and discussion. Reading increases knowledge and broaden your horizons. Observation is an effort to gain a profound new knowledge, so the artists get new ideas. When experiencing lack of ideas, artists brainstorming ideas can be freely made in order to avoid deadlock ideas. Lateral thinking is a way of refreshing the mind trying to get out of the box stability, routine, or the ideology, in order to find innovative ideas in the creation of art. Socializing and discusing multiply with friends to exchange ideas and getting inspirative experiences.
\end{abstract}

\footnotetext{
* Edi Eskak (eskakedi@gmail.com), Staff pada Balai Besar Kerajinan dan Batik Yogyakarta
} 
Keywords: ideas, creativity, and artistic creation.

\section{PENDAHULUAN}

Seni merupakan salah satu hasil kreativitas dan ekspresi manusia. Seni menjadi salah satu identitas budaya dan eksistensi suatu bangsa. Eksistensi kesenian suatu bangsa merupakan akumulasi dari eksistensi individu-individu dan kelompok-kelompok warga yang berkesenian atau berkarya seni. Eksistensin seniman dibangun dengan senantiasa berkarya dan menyosialisasikan karyanya ke publik. Untuk meciptakan karya-karya yang inovatif dan mempunyai nilai orisinalitas diperlukan ide atau gagasan sebagai titik tolak penciptaan berkarya. Tanpa didahului ide, seniman tidak akan bisa berkarya. Itulah arti penting ide atau gagasan dalam berkarya seni, namun dalam penciptaan karya seni banyak seniman sering kali terkendala dalam menemukan ide atau gagasan yang akan dituangkan menjadi karya. Ide adalah pokok isi yang dibicarakan oleh seniman atau desainer melalui karya-karyanya (Susanto, 2011: 187). Padahal dalam membuat karya seni persoalan penting yang pertama adalah mendapatkan ide kreatif yang akan dijadikan titik tolak penciptaan. Kreatif berarti memiliki daya cipta atau memiliki kemampuan untuk berkreasi, sedangkan kreasi berarti hasil daya cipta manusia baik yang berupa hasil seni maupun hasil otak atau pikiran (Badudu, 1996: 723). Untuk itulah dalam tulisan ini dikaji berbagai metode pembangkitan ide kreatif dalam penciptaan karya seni. Penciptaan karya seni yang dimaksudkan di sini adalah bisa penciptaan karya secara individual maupun secara berkelompok.

\section{METODOLOGI}

Kajian ini menggunakan data yang diperoleh dari buku-buku yang membahas tentang teori-teori kreativitas dan pengamatan terhadap kebiasaan seniman kreatif. Metode untuk membangkitkan ide kreatif yang akan dikaji dalam tulisan ini adalah: membaca, , observasi, curah gagasan, berpikir lateral, serta bergaul dan berdiskusi.

\section{PEMBAHASAN}

\section{Membaca}

$\begin{array}{llr}\text { Kegiatan } & \text { membaca penting } \\ \text { dilakukan oleh } & \text { seniman karena } & \text { akan } \\ \text { memperkaya } & \text { pengetahuan } & \text { yang }\end{array}$ bermanfaat dalam aktivitas kreatif. Membaca adalah menyuarakan atau melisankan huruf-huruf (nyaring atau dalam hati saja) untuk mengetahui informasi tertulis (Badudu, 1996: 101). Ungkapan klise "membaca dapat membuka jendela dunia" memang benar adanya karena mendapatkan pengetahuan baru yang bisa merangsang seniman mendapatkan ide-ide baru. Seniman kreatif banyak diantara mereka merupakan kutu buku, seperti Heri Dono seniman yang berkiprah dalam ajang seni internasional dalam setiap karyanya mempunyai makna filosofi dan mengandung kritik sosial budaya yang tajam refleksi dari pengetahuan yang luas dan aktual yang didapatkan dari berfikir, berkreativitas, dan membaca. Komunitas seni Taring Padi dari 
Yogyakarta, yang karyanya berisi kritik sosial budaya yang radikalpun melandasi kajian-kajian konsep berkarya dengan membaca buku sebagai kepedulian intelektual dan membaca realitas masyarakat bawah (nasib buruh, petani, nelayan, orang tertindas) sebagai kepedulian aktual.

Membaca merupakan suatu cara untuk mendapatkan informasi dari sesuatu yang tertulis. Informasi-informasi pengetahuan yang penting untuk konsumsi otak kita, sebagaimana pentingnya konsumsi makanan untuk tubuh kita. Manfaat membaca bagi seniman antara lain: (1) Meningkatkan kretivitas. Membaca tentang keanekaragaman kehidupan akan memperkaya pengetahuan. Pengetahuan akan merangsang ide-ide baru dan mengembangkan kreativitas seniman, karena otak mendapatkan energi dan bahan pikiran baru dari kegiatan membaca. (2) Menyehatkan otak. Membaca merupakan proses mental secara aktif yaitu menggunakan otak untuk menyerap pengetahuan dengan berkonsentrasi karena banyak hal baru yang belum diketahuai. Dalam proses ini sel-sel otak kita terisi dengan pengetahuan baru yang yang dapat digunakan untuk berfikir dan menambah kepintaran. (3) Mendapatkan pengetahuan dan meningkatkan ketrampilan bahasa tulis. Membaca dan mendengar adalah cara untuk mendapatkan informasi. Membaca melibatkan pengenalan simbol yang menyusun sebuah bahasa. (4) Meningkatkan memori. Banyak penelitian yang menunjukkan bahwa jika seseorang tidak menggunakan memori dalam pikirannya, maka memori tersebut bisa kurang berfungsi bahkan akan hilang. Membaca akan membantu meregangkan memori otak. Membaca itu memerlukan ingatan terhadap detail, fakta dan gambar pada suatu literatur, alur, tema atau karakter cerita. Membaca dan permainan kata seperti teka-teki silang dapat mencegah penyakit alzheimer, yaitu penyakit menurunya fungsi otak ditandai dengan semakin mengecilnya massa sel otak. (5) Membangun kepercayaan diri. Semakin banyak membaca, semakin banyak pengetahuan yang didapatkan. Dengan bertambahnya pengetahuan, akan semakin membangun kepercayaan diri.

\section{Observasi}

Observasi adalah pengamatan, namun pengamatan yang dilakukan secara cermat dan mendalam terhadap suatu objek atau permasalahan. Observasi merupakan kata serapan dari bahasa Inggris "observation" yang artinya pengamatan, peninjauan secara cermat (Badudu, 1996: 41), sedangkan kata kerjanya adalah mengamati (to observe) yang artinya mengawasi dengan teliti, mengobservasi. Dari pengertian tersebut dapat dipahami bahwa observasi tak lain adalah pengamatan secara mendalam, detil dan terperinci terhadap suatu objek sehingga mendapatkan insight. Insight yaitu pemahaman baru yang lebih mendasar/mendalam dari objek atau permasalahan yang diamati.

Melakukan observasi jangan hanya terpaku pada tampilan luarnya saja tetapi berusaha bersungguh-sungguh untuk mengetahui lebih dalam apa saja yang terkandung pada objek atau permasalahan. Maka perlahan-lahan akan muncul 
berbagai pertanyaan yaitu $5 W+1 \mathrm{H}$ (Who, What, Where, When, Why + How), siapa, apa, dimana, kapan, mengapa dan bagaimana. Pengamatan objek secara mendalam dan mengasyikkan tanpa disadari akan memuncul ide-ide baru yang tidak pernah terduga sebelumnya. Insight yang didapat akan membuka berbagai peluang yang bisa digunakan sebagai ide sumber inspirasi penciptaan karya seni.

Langkah-langkah observasi yang bisa dilakukan adalah: (1) Mengamati objek atau permasalahan secara mendalam, bisa dengan mengajukan pertanyaan, mendengar, menyentuh, dan lain sebagainya. Optimalkan peran panca indera dalam observasi. Semakin diamati dan diperhatikan secara seksama maka pengalaman dan pemahaman terhadap objek semakin terlihat dan terasa. (2) Mencatat secara rinci hasil observasi, menyangkut wujud, material, ukuran, unsur-unsur lain atau kondisi subjektif ataupun makna-makna yang muncul setelah pengamatan. Hasilnya disadari atau tidak dari pengamatan secara mendalam adalah objek yang tadinya kurang menarik ternyata sangat menarik, yang biasa saja menjadi luar biasa, yang tadinya tidak berguna ternyata bisa bermanfaat dan sebagainya. (3) Melengkapi pengamatan mendalam tadi dengan teori-teori pendukung dalam mengambil pemahaman tentang sesuatu yang diamati. Teori pendukung ini berguna untuk memperkuat argumentasi konsep penciptaan karya seni yang akan dibuat.

Observasi merupakan suatu keahlian (skill) yang harus dilatih atau dipraktekkan. Pengamatan tidak harus formal dengan alat bantu observasi yang lengkap. Setiap orang dapat belajar untuk menjadi pengamat yang lebih baik misalnya dengan memperhatikan lingkungannya dengan lebih seksama. Pengamatan menghasilkan pengetahuan baru, banyak hal yang tadinya tidak ada yang menjadi ada setelah diamati keberadaannya. Melalui pengamatan berbagai macam pemaknaan dan peluang akan terbuka. Sesuatu yang tadinya tak terpikirkan oleh kita menjadi lebih berarti dengan pengamatan yang mendalam.

\section{Curah Gagasan}

Banyak seniman ataupun desainer sering mengalami ketiadaan atau kehabisan ide (blank) ketikan akan berkarya. Hal ini terjadi karena otak tidak mengeluarkan ide. Kebiasaan menyaring pemikiran menjadikan kehati-hatian yang merugikan, yaitu tersendatnya keluarnya inspirasi dari otak, maka perlu suatu metode untuk melancarkan ide-ide yang tersendat itu. Curah gagasan atau brainstorming merupakan suatu metode mengeluarkan ide secara langsung dan tidak perlu menyaring ide-ide yang terlintas dalam pikiran. Curah gagasan bisa dilakukan secara individu maupun kelompok dengan mengasosiasikan permasalahan secara bebas serta keleluasaan berfikir guna menjaring ide baru dan segar untuk mencari solusi atas suatu permasalahan. Menurut Mendiola (2008: 19), brainstorming adalah proses pengumpulan ide lewat urun rembug pendapat masing-masing peserta diskusi. Pada tahap awal biasanya ide dibiarkan berkembang tanpa batasan, lalu pada proses selanjutnya ide disaring lewat berbagai pertimbangan dan pendekatan 
sehingga mengkristal dan menghasilkan akumulasi ide yang cemerlang.

Curah gagasan dilakukan dengan cara menuliskan atau menggambarkan secara cepat apapun yang terlintas dalam pikiran mengenai topik tertentu. Tulisan berupa satu atau dua kata yang jelas, bisa juga gambar sketsa simbol sederhana yang informatif. Curah gagasan bisa dilakukan oleh individu atau kelompok orang biasanya dilakukan selama 60 menit untuk memunculkan ide yang bebas, liar dan baru sama sekali dalam upaya untuk menghasilkan konsep baru. Metode curah gagasan sebagai upaya membebaskan pikiran dari hal-hal yang menghambat timbulnya ide, yaitu kebiasaan belum apaapa sudah mengkritisi, menilai dan mengevaluasi. Saat mengikuti sebuah grup curah gagasan kita tidak usah canggung untuk mengeluarkan ide. Curah gagasan dalam sebuah tim tak ubahnya seperti rapat cepat dengan masing-masing peserta mencurahkan pendapatnya. Bila melakukan curah gagasan secara individu, tidak perlu takut menuliskannya secara cepat apapun yang terpikirkan saat itu juga, tidak perlu menimbang-nimbang, mengkritisi dan mengevaluasi, karena itu akan menghambat curahan ide-ide yang lain.

Curah gagasan merupakan teknik metode kerja berfikir cepat modern yang telah dikenal sejak tahun 1938. Tekniknya sangat sederhana, tetapi efeknya besar sekali. Satu kelompok orang berkumpul untuk mengutarakan gagasan-gagasannya secara bebas dan dilakukan tidak dengan kritikan sama sekali. Semakin liar dan gila, ide-ide yang muncul semakin baik. Nanti, setelah tercurah segala pemikiran, baru dilakukan fase analisis dan pembahasan guna mengkategorikan gagasan dan memilih beberapa gagasan yang baik untuk dibahas lebih mendalam (Kelly dalam Marianto, 2006: 5-6). Dalam fase inilah baru saatnya kita melakukan mengkritisi, menilai dan mengevaluasi.

Manfaat melakukan curah gagasan adalah: (1) Menghasilkan ide yang banyak, dan dari sekian banyak ide pasti diantaranya terdapat ide cemerlang. (2) Memberi perasaan fantastis dan memperkaya pengalaman karena menghasilkan curahan ide yang kadang di luar dugaan. (3) Dapat merajut ide-ide menjadi satu kesatuan untuk menemukan solusi terbaik dalam pemecahan suatu masalah. (4) Dapat melatih meregangkan pikiran untuk menyelesaikan permasalahan dengan cara yang berbeda. (5) Dapat menghasilkan sesutu yang bermanfaat, melatih kemampuan kepercayaan diri untuk berbicara di depan forum (Kelly, 2001: 81).

Curah gagasan dalam penciptaan seni bertujuan untuk: (1) Melancarkan dalam mencurahkan ide-ide dalam pikiran yang mengendap maupun yang sekedar terlintas. (2) Mengeksplorasi ide-ide kreatif secara bebas. (3) Mencari solusi alternatif ketika menyelesaikan suatu permasalahan. (4) Berani menyampaikan ide yang berbeda. (5) Melatih kecepatan berfikir dan mengingat. (6) Menyampaikan secara terorganisir dan demokratis dari pendekatan sampai pemecahan masalah untuk individu maupun kelompok. (7) Mendapatkan ide yang banyak. 


\section{Berpikir Lateral}

Prinsip dasar berpikir lateral adalah setiap cara khusus untuk melihat sesuatu di antara banyak kemungkinan cara lain. Istilah lateral sendiri menunjukan gerakan ke samping untuk mengembangkan polapola informatif tertentu. Berpikir lateral saat ini telah menjadi salah satu alat bantu berpikir kreatif terbaik, jika tidak bisa dikatakan yang terbaik dan juga ikut menginspirasikan berbagai alat bantu berpikir kreatif lainnya. Cara ia bekerja adalah dengan memotong pola berpikir untuk menciptakan perspektif dan persepsi baru dan berbeda. Otak manusia adalah sistem mandiri dalam mengorganisasi berbagai hal, yang secara rutin mengorganisir input ke dalam pola-pola. Berpikir lateral memungkinkan kita untuk bergerak secara lateral memotong polapola, dan oleh sebab itu membuka persepsi baru, konsep dan ide baru.

Menurut Bono (1991: 41-47), berfikir vertikal mempunyai perbedaan dengan berfikir lateral. Adapun perbedaannya adalah sebagai berikut:

1. Berpikir vertikal hanya bergerak bila terdapat suatu arah untuk bergerak, berpikir lateral bergerak agar dapat mengembangkan satu jurusan.

2. Berpikir vertikal bersifat analitis, dan berpikir lateral bersifat provokatif.

3. Berpikir vertikal adalah berurutan, sedangkan berpikir lateral dapat membuat lompatan.

4. Dengan berpikir vertikal kita harus tepat pada setiap langkah, dengan berpikir lateral kita tidak harus tepat pada setiap langkah.

5. Dengan berpikir vertikal kita menggunakan kaidah negatif agar dapat menutup jalur jalan tertentu. Dalam berpikir lateral tidak ada kaidah negatif.

6. Dengan berpikir vertikal kita memusatkan perhatian dan mengesampingkan sesuatu yang tidak relevan, dengan berpikir lateral kita menerima semua kemungkinan dan pengaruh luar.

7. Dengan berpikir vertikal kategori klasifikasi, dan label-label telah terpatri, dengan berpikir lateral tidak.

8. Berpikir vertikal mengikuti jalur yang paling tepat, berpikir lateral menjelajahi yang paling tidak tepat

9. Berpikir vertikal adalah suatu proses yang terbatas, berpikir lateral adalah suatu serba kemungkinan.

Metode kreatif berfikir lateral mempunyai keunggulan fungsi sebagai mana penjelasan Marianto (2006: 121) yaitu: (1) Berkaitan dengan upaya meninjau kembali pola pandang kita dalam mengorganisasi informasi. (2) Berpikir lateral adalah upaya mengubah persepsi kita terhadap suatu objek atau permasalahan. (3) Dengan berpikir lateral kita mencari berbagai cara pandang terhadap suatu permasalahan. Semua cara pandang itu benar dan dapat ko-eksis. Setiap cara pandang yang ada itu tidak bermula dari cara pandang yang lain, tetapi dihasilkan secara sendiri-sendiri dan mandiri. (4) Dalam pemahaman ini, berpikir lateral harus berhubungan dengan eksplorasi sebagaimana persepsi harus berhubungan dengan eksplorasi.

Dari uraian di atas dapat ditarik kemanfaatan dari berfikir lateral bagi seniman antara lain: (1) Dapat digunakan dalam mengatasi kebekuan pola pandang, 
sebagai upaya membangkitkan persepsipersepsi alternatif, melihat permasalahan dari sudut pandang yang berbeda guna merombak habitus lama (pola pikir, cara pandang, yang dibawa sehari-hari yang terbentuk karena lingkungannya), merubah pola pikir yang tadinya linier menjadi non lynier dynamic (berpikir keluar dari kotak atau pagar). (2) Berpikir lateral adalah salah satu cara agar kita keluar dari kotak kemapanan, rutinitas, atau dari penjara idiologi guna untuk menelurkan kreativitas dan inovasi. (3) Berpikir lateral yang tetap bertumpu kepada berbagai fakta yang ada, kemudian menentukan hasil akhir yang diinginkan, dan selanjutnya secara kreatif mencari alternatif pemecahan masalah dari berbagai sudut pandang yang paling mungkin mendukung hasil akhir tersebut, dapat digunakan dalam menghadapi dan memecahkan berbagai persoalan kerja profesional, seni, rumah tangga dan hidup sosial bermasyarakat, dengan hasil yang lebih baik dan kreatif. Berfikir lateral menghasilkan banyak ide alternatif sehingga seniman terhindar dari kebuntuan ide.

\section{Bersosialisasi dan berdiskusi}

Bersosialisasi merupakan fitrah manusia dalam berkehidupan termasuk seorang seniman. Bersosialisasi artinya adalah bermasyarakat atau berhubungan dengan masyarakat (Badudu, 1996: 1350). Bersosialisasi merupakan suatu proses di mana setiap individu manusia mempelajari, menerima dan menyesuaikan diri dengan berbagai unsur kebudayaan dalam masyarakat, seperti adat istiadat, nilai, norma, perilaku, bahasa, kesenian, dan sebagainya. Bersosialisasi berlangsung sejak seseorang masih bayi sampai orang tersebut meninggal. Bersosialisasi merupakan bagian dari eksistensi berkesenian. Seniman sebagai warga masyarakat bersosialisasi dengan lingkungan sekitarnya akan mendapati berbagai problematika sosial yang merupakan bahan inspirasi penciptaan karya seni. Bersosialisasi memeperluas pergaulan juga menambah pertemanan serta menambah daya peka atau sensitivitas seniman. Pertemanan atau keberadaan orang lain disekitar kita dengan kapasitasnya masing-masing merupakan sumber pemikiran-pemikiran alternatif yang dapat membuka pikiran kreatif seorang seniman melalui komunikasi yaitu diskusi. Diskusi tidak harus formal, yang penting apa yang dibicarakan berkualitas dan mampu membangkitkan ide-ide kreatif.

Diskusi merupakan bentuk pertemuan atau interaksi verbal dengan orang lain untuk membahas sesuatu permasalahan. Diskusi berasal dari kata "discum" (bahasa latin) dan "discussio" (bahasa inggris) yang artinya adalah interaksi. Diskusi adalah pertemuan untuk bersoal jawab tentang suatu masalah (Badudu, 1996: 350). Peserta diskusi harus saling aktif bertukar pikiran dalam menentukan alternatif pemecahan masalah. Diskusi dapat sebagai wahan respon antara pribadi yang akhirnya menghasilkan kesepakatan bersama. Efek positif diskusi bagi seorang seniman adalah dapat mengembangkan pribadi, harga diri, hormat kepada sesama, berani mengaungkapkan pendapat dan mendalami pengertian tentang suatu persoalan, serta mendapatkan pengetahuan/informasi baru yang merangsang kreativitas. Pelukis senior $\mathrm{H}$. Widayat pernah menyatakan bahwa dirinya sering mendapat ideide penciptaan lukisan atau keramik setelah 
mengajar dan berdiskusi dengan para mahasiswanya dalam kelas kuliah penciptaan seni yang diasuhnya di STSRI "ASRI" Yogyakarta (sekarang ISI Yogyakarta).

Diskusi dilakukan untuk tujuan: (1) Mengungkapkan pendapat dan respon dari suatu pemikiran sendiri atau orang lain. (2) Bertukar pikiran dan ide yang ada relevansinya. (3) Mengaitkan data dan keadaan dari berbagai pandangan orang lain dengan latar belakang yang berbeda-beda. (4) Menguji secara kolektif tentang suatu ide. Adapun manfaat dari kegiatan berdiskusi antara lain yaitu: (1) Termotivasi untuk lebih memahami masalah dilingkungannya sebagai diri sendiri, keluarga, masyarakat, organisasi, dan lingkungan lainnya yang lebih luas. (2) Latihan merumuskan buah pikiran yang jelas, singkat, dan komunikatif. (3) Membina dan melatih jiwa sabar, toleransi, terbuka serta tidak egoistis. (4) Mengembangkan ketrampilan berpikir, kestabilan emosi, dan kedewasaan sikap. (5) Mendapatkan masukan-masukan inspiratif untuk diolah menjadi ide-ide kreatif penciptaan seni.

\section{KESIMPULAN DAN SARAN}

\section{Kesimpulan}

Daya kreatif penciptaan seni dapat dibangkitkan dengan metode ilmiah yaitu: membaca, observasi, curah gagasan, berpikir lateral, serta bersosialisasi dan berdiskusi. Obsevasi akan mendapatkan pengetahuan baru yang mendalam melalui pengamatan, sehingga akan didapatkan ide-ide baru. Curah gagasan yang dilakukan secara bebas dapat memperlancar keluarnya ide-ide baru. Berpikir lateral dapat memperluas dan membebas pikiran, serta menghindari rutinitas yang menyebabkan kebuntuan ide. Bersosialisasi dan berdiskusi memperbanyak teman untuk bertukar pikiran serta mendapatkan pengalaman yang inspiratif.

\section{Saran}

Mempraktekan metode-metode tersebut secara rutin dan konsisten akan meningkatkan daya kreatif. Perlu juga dilakukan kajian-kajian lebih lanjut tentang metode pembangkitan ide kreatif untuk penciptaan seni dalam perspektif yang lain.

\section{DAFTAR PUSTAKA}

Badudu, J. S., dan Sutan Muhammad Zain, 1996, Kamus Umum Bahasa Indonesia, Pustaka Sinar Harapan, Jakarta.

Debono, Edward, 1967, The Use of Lateral Thinking', Terjemahan Bahasa Indonesia, 1991, Binarupa Aksara, Jakarta. .

1991, Lateral Thinking, Diterjemahkan oleh Sutoyo, Jakarta: Erlangga.

Ellfers, Joost, 1978, Tangram The Ancient Chinese Shape Games, Penguins Books, New York.

Kelly, Tom, 2001, The Art of Inovation, Diterjemahkan oleh Paulus Herlambang, 2002, Gramedia, Jakarta.

Marianto, M. Dwi, 2006, Quantum Seni, Daharaprize, Yogyakarta.

Rich, R. Jason, 2003, Brainstorming: Tap into Your Creativity to Generate Awesome Ideas and Remarkable Result, Book-mart Press, New Jersey.

Susanto, Mikke, 2011, Diksi Rupa, DictiArt Lab, Yogyakarta. 